\title{
Sustainability assessment of biogas production from buffalo grass and dung: biogas purification and bio-fertilizer
}

\author{
Ajcharapa Chuanchai ${ }^{1} \cdot$ Rameshprabu Ramaraj $^{1,2}$ (D)
}

Received: 16 January 2018 / Accepted: 6 February 2018 / Published online: 26 February 2018

(c) The Author(s) 2018. This article is an open access publication

\begin{abstract}
Biomass from wetland aquatic grass and buffalo grass can be exploited for biogas production, because this substrate is plenteous and does not compete with food production. In this study, the grass substrate was physically pretreated by boiling with different retention time to increase its biodegradability and was examined in batch mode. Boiling pretreatment suggested that $100{ }^{\circ} \mathrm{C}$ with $2 \mathrm{~h}$ retention time was the best condition. The results showed that the optimum grass concentration in the 1:1 ratio of co-digestion mixture with manure produced the highest methane yield. The results suggested that co-digestion of buffalo grass and buffalo dung was a promising approach for improving biogas production. This study was achieved the upgraded biogas through biological purification contained $90.42 \% \mathrm{CH}_{4} 8.04 \% \mathrm{CO}_{2} 1.43 \% \mathrm{O}_{2}$ and $0.11 \%$ other trace gasesa remarkable performance based on an efficiency criteria. Furthermore, the digestate has high nutrient concentrations that can potentially use as fertilizer.
\end{abstract}

Keywords Buffalo grass $\cdot$ Buffalo dung $\cdot$ Biogas production $\cdot$ Methane enhancement

\section{Introduction}

The environmental and global warming consciousness has become an important policy in all countries around the world. Furthermore, the fossil fuel use has been related to some alarming environmental problems such as global warming and climate change (Tsai et al. 2016; Vu et al. 2017). These increasing demands for energy, together with the weakening and limited source of fossil fuels, together with the harmful impacts in the environment, are the reasons industries and governments worldwide are pursuing renewable alternatives. Bioenergy, a renewable energy sources, draws responsiveness due to its accessibility and low carbon dioxide emission (Ramaraj et al. 2016a, b ,c). Thai government has increasingly given an importance on how to solve this problem issues among the first priority in local development.

Rameshprabu Ramaraj

rrameshprabu@gmail.com; rameshprabu@mju.ac.th

1 School of Renewable Energy, Maejo University, Chiang Mai 50290, Thailand

2 Energy Research Center, Maejo University, Chiang Mai 50290, Thailand
At present, many agencies have focused on renewable energy such as solar energy, wind energy, hydroenergy and geothermal energy. Renewable sources of energy and consumer products are required for sustainable development of modern society (Unpaprom et al. 2017; Vu et al. 2017). Energy demand required to meet the economic growth of Thailand is growing higher in every year (Dussadee et al. 2017). Accordingly, Thailand has a huge potential to develop renewable energy from biomass as the country has an abundant agriculture sources such as raw materials from crops and livestock that can be used to produce biogas, specifically methane gas, through the decomposition of organic matter in the system (Dussadee et al. 2014; Vu et al. 2018).

Plant biomass is the main source of renewable materials on Earth and represents a potential source of renewable energy and bio-based products (Guo et al. 2015; Wannapokin et al. 2017). Animal manures have been used as a resource of excellent material for anaerobic digestion (AD) with clear environmental benefit, especially for buffalo dung. Since Thailand economy depends mainly on agriculture activities, therefore, utilization of natural resources for energy production is an extremely important issue. Agricultural residues from the agricultural sector, agriculture industry and grassland biomass are usually used as feed materials in anaerobic digestion systems in Thailand which 
are suitable in numerous ways for producing energy. There are so many types of grasses that are popularly grown in Thailand (Dussadee et al. 2017). Deb et al. (2016) stated that the buffalo grass, traditionally raised in a mixed crop livestock system, has played an important role over the centuries, especially in Asia, for the lives of millions of people, by ensuring work power and food at the end of their career as work animals.

Buffalo grass a tropical and invasive growing plant in rural area has only value to be feedstock for animal feeding. These exotic grass weeds are overgrown in abundantly available resources in the Northern region of Thailand. It needs to cut down and removed frequently for fire hazard, and disease and vector controls (Sahoo et al. 2017). The present study investigates the possibility of buffalo grass as a feedstock for biogas production using certain pretreatment. Rösch et al. (2013) stated that grass is converted to silage that can be used as feedstock for anaerobic digestion. This can be utilized as raw materials for an environmentally friendly renewable energy, more specifically for biogas production. Additionally, the use of grassland biomass for the biogas production is currently the common practice. Biogas application includes ensuring energy security, decreasing carbon emission and improving economic activity. It can be produced by a single raw material such as pig manure, cow manure and buffalo manure. Furthermore, Thailand is being in top 11 in the countries of Asia for buffalo population.

In present, the production of biogas has been evolving to enhance the efficiency like co-digestion of buffalo dung with grass. Co-digestion of buffalo grass (para grass) with buffalo dung in farm's around community existing digester becomes a valid approach to enhance biogas production Also, the addition of grass can help raise C: $\mathrm{N}$ of the feedstock to be suitable for metabolic activities in anaerobic digestion system. The physical structure and chemical composition of lignocellulosic materials can be altered through various methods of pretreatment, breaking down the linkage between polysaccharides and lignin, thus making cellulose and hemicelluloses more accessible to hydrolytic enzymes (Wannapokin et al. 2018). Therefore, pretreatments could accelerate the hydrolysis process and improve the methane content in the biogas.

Strevett et al. (1995) stated that water vapor in biogas is problematic for compressibility and should be removed prior to storage. And biogas typically contains a high percentage of carbon dioxide $\left(\mathrm{CO}_{2}\right)$, which decreases its caloric value. Finally, hydrogen sulfide $\left(\mathrm{H}_{2} \mathrm{~S}\right)$, which is also present in biogas, is toxic and exhibits corrosive effects on process equipment if not removed prior to compression and storage. Physicochemical methods such as physical adsorption, physical absorption or chemical absorption are commonly used to treat biogas. However, these biogas purification methods require costly investment and maintenance which are not suitable for industrial scale and reduce the profit. Therefore, biological purification that takes advantages of photosynthesis process of plant such as microalgae to eliminate $\mathrm{CO}_{2}$ from biogas can be applied to reduce the capital and operations cost as enhance the biogas quality (Ramaraj et al. 2016a, b ,c). Therefore, this study main aim is to assess different pre-treatment and fermentation techniques through experimentation and evaluate each process and improvement of biogas yield. Finally, biogas production from buffalo grass (Brachiaria mutica) co-digestion with buffalo dung) through anaerobic enhanced methane content achieved by microalgae pass biological purification. Additionally, this study aimed to use non-food plant source as a feedstock for biogas production, a renewable energy fuel.

\section{Materials and methods}

\section{Collection and preparation of substrates}

The study methodology is illustrated in Fig. 1. This experimental study was carried out at an Energy Research

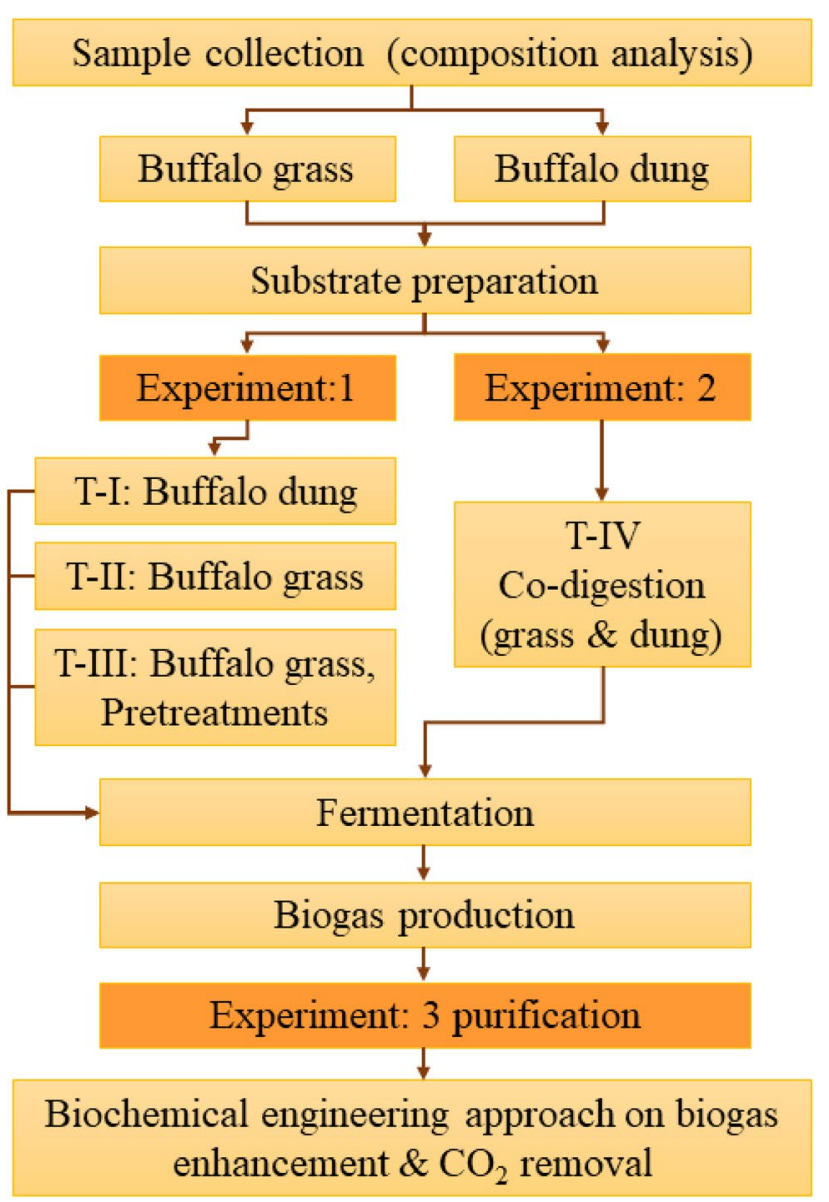

Fig. 1 The flowchart of study methodology 
Center (ERC), Maejo University, Chiang Mai, Thailand $\left(18^{\circ} 53^{\prime} 35^{\prime \prime} \mathrm{N}\right.$; $\left.99^{\circ} 01^{\prime} 10^{\prime \prime} \mathrm{E}\right)$; additionally, the buffalo grass and buffalo dung were collected near to the experimental zone. The grass sample was crushed by a machine into small particles. Stored grass was pulverized into small particles $(1.0 \mathrm{~mm})$ before use. The inoculum was utilized from the Maejo pig farms located at the University campus. For biogas purification, the microalgae were obtained from ERC and the culturing details were described by Ramaraj et al. $(2016 a, b, c)$.

\section{Experimental setup}

The buffalo grass was pretreated with boiling water at $100{ }^{\circ} \mathrm{C}$ with different reaction time ranging from 0.5 to $2 \mathrm{~h}$. The experiments were carried out in batch type laboratory scale reactors and were categorized based on the different treatments applied: T-I (no treatment, buffalo dung), T-II (no TREATMENT, buffalo grass), T-III-A (buffalo grass, boiled $100{ }^{\circ} \mathrm{C} 0.5 \mathrm{~h}$ ), T-III-B (buffalo grass boiled $100{ }^{\circ} \mathrm{C}$ $1 \mathrm{~h}$ ), T-III-C (buffalo grass, boiled for $1.5 \mathrm{~h}$ at $100{ }^{\circ} \mathrm{C}$ ), T-III-D (buffalo grass, boiled for $2 \mathrm{~h}$ at $100{ }^{\circ} \mathrm{C}$ ) and T-IV (co-digestion of buffalo dung and buffalo grass, boiled for $2 \mathrm{~h}$ at $100{ }^{\circ} \mathrm{C}$,). Experiment T-IV was operated with 1:1 ratio of grass and dung. Each reactor was made from a $7 \mathrm{~L}$ plastic container placed in a water bath. All reactors with $5 \mathrm{~L}$ working volume were run simultaneously for 35 days. The schematic configuration of the anaerobic biogas reactor system is given in Fig. 2. The accumulated biogas was stored carefully until the sufficient volume for purification experiments was reached.

\section{Analytical methods}

Parameters such as total solid (TS), volatile solids (VS), fixed solids (FS), chemical oxygen demand (COD), ash and moisture contents were measured according to the standard methods (APHA 2005). The compositions of sample (cellulose, hemicellulose, and lignin) were determined by

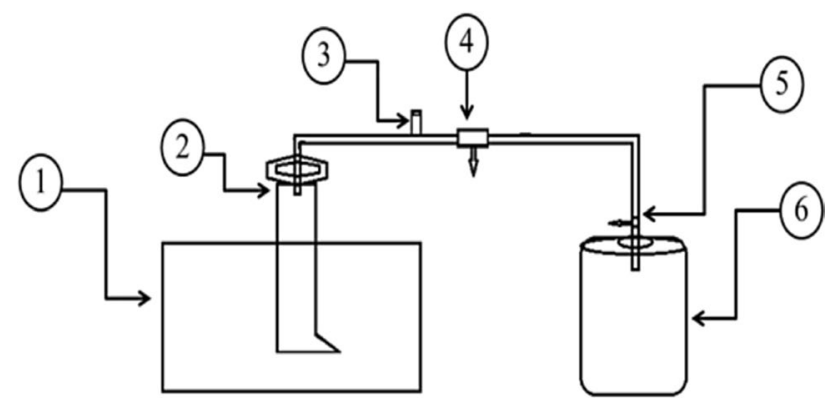

Fig. 2 The digester (1) water bath, (2) gas holder, (3) gas release valve, (4) gas line connecter, (5) gas line tube and (6) fermenter
Van Soest method (Van Soest et al. 1991). Metrohm 774 $\mathrm{pH}$ meter was used in all $\mathrm{pH}$ measurements. The $\mathrm{pH}$ was adjusted ranging from 7.40 to 7.70 for all experiments. Direct titration method for the determination of total volatile fatty acids and alkalinity was used (Ennouri et al. 2016). Samples were titrated with $0.1 \mathrm{~N} \mathrm{HCl}(\mathrm{pH}=3)$, boiled over 3 min to remove $\mathrm{CO}_{2}$, then back-titrated using $0.1 \mathrm{~N} \mathrm{NaOH}$ until the $\mathrm{pH}$ reached 6.5 . The biogas volume produced from the batch digester was determined using a water displacement unit. The $\mathrm{pH}$ of the substrate and digestate was determined using $\mathrm{pH}$ meter. The concentration of methane $\left(\mathrm{CH}_{4}\right)$ and other gases including carbon dioxide $\left(\mathrm{CO}_{2}\right)$, hydrogen sulfide $\left(\mathrm{H}_{2} \mathrm{~S}\right)$, and oxygen $\left(\mathrm{O}_{2}\right)$ in biogas produced were all determined by a portable gas analyzer (BIO5000, UK). The volume of biogas produced was measured at daily basis and biogas compositional analysis was performed every 3 days. The samples were analyzed for organic carbon, nitrogen (alkaline $\mathrm{KMnO}_{4}$ method), $0.5 \mathrm{M} \mathrm{NaHCO}_{3}$ (pH 8.5) extractable $\mathrm{P}$ and $1(\mathrm{~N}) \mathrm{NH} 4 \mathrm{OAc}$ - extractable $\mathrm{K}$ and other trace elements (Page et al. 1982). In addition, emission, atomic absorption, volumetric, colorimetric, and photometric methods were used to determine physicochemical digestate properties and measurements adopted from Kinyua et al. (2016).

Calorific values were estimated according to $\mathrm{Li}$ et al. (2014).The higher calorific values (HCV) and lower calorific values (LCV) of pure methane were 39.82 and $35.87 \mathrm{MJ} /$ $\mathrm{m}^{3}$, respectively. HCV and LCV of produced biogas were determined according to the following formula:

$\mathrm{HCV}_{\text {biogas }}=0.3989 \times \mathrm{MC}=0.0213\left(R^{2}=1\right)$

$\mathrm{LCV}_{\text {biogas }}=0.3593 \times \mathrm{MC}=0.0192\left(R^{2}=1\right)$

where $\mathrm{MC}$ is the methane content in biogas (\%).

\section{Characterization of pretreated and untreated biomass}

The biomass was characterized using scanning electron microscope, in order to observe the changes on the structure before and after applying pretreatment, characterization of biomass was done analysis using scanning electron microscopy analysis (JSM-5410LV, USA). The observation was performed at a total magnification of $100 \times$.

\section{Biogas through biological purification}

Biogas enhancement was performed through photoautotrophic microalgae (Chlorella vulgaris). The experiment was continued for $8 \mathrm{~h}$. Two types of biogas flow rate $(0.9$ and $1.8 \mathrm{lpm}$ ) in the algae growth unit were applied. The biological biogas purification process is described in Fig. 3 . 
Fig. 3 Biogas enhancement through biological purification system

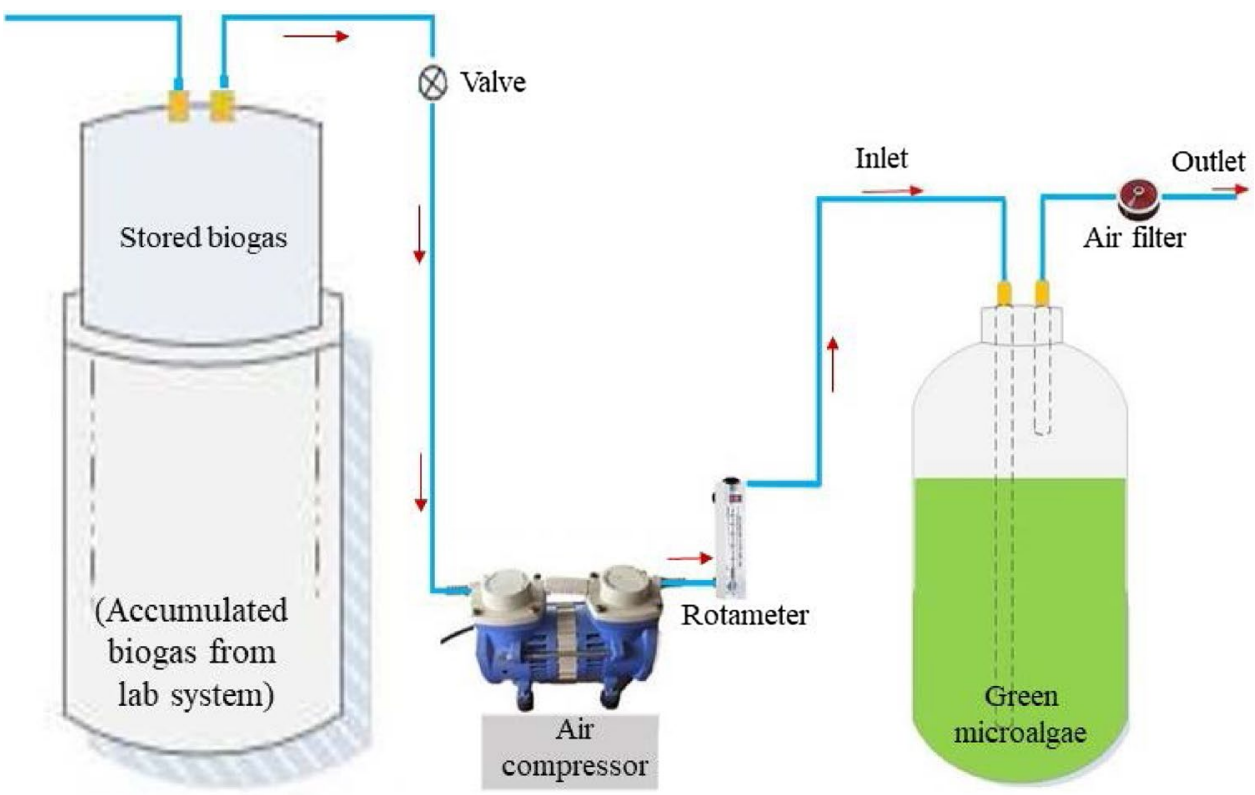

carried out to assess changes in morphology of the native and pretreated samples boiled at $100{ }^{\circ} \mathrm{C}$ with $2 \mathrm{~h}$ retention time. Figure 4a shows the SEM micrograph of native buffalo grass stem, the surface of which shows to have a regular and compact structure. Morphological changes induced by boiling are first noticeable after a pretreatment on buffalo grass stem, as shown in Fig. 4b.

A slight defibrillation was observed (shown in Fig. 4c, d); the separation of individual fibers, enlargement of the reactive area and more pronounced structural changes in the biomass were seen due to a possible solubilization of the hemicellulose. As hemicellulose operates as a cementing material, its solubilization causes a significant defibrillation effect on the biomass. In addition, a reduction in fiber length and the formation of entangled clusters can be seen in Fig. 4e, f; the fiber structure was almost entirely disintegrated due to the higher solubilization of hemicellulose and lignin re-localization. It was found that the fibers were greatly affected by boiling with $2 \mathrm{~h}$ retention time. In addition, the swelling of fibers is also observed in boiling pretreated biomass. This result was also supported by the structural changes observed from the SEM images of the stem, upper and lower leaf epidermis of the buffalo grass samples.

\section{Pretreatment and biogas production}

Hydrothermal pretreatment in lignocellulosic feedstock involves the usage of water only and has been widely accepted as a green technology without potential chemical consumption and potential pollution (Saha et al. 2013). Typically, it can remove most of hemicellulose and part of lignin in biomass by degrading them into soluble frac-

tions and loosening the recalcitrant structure as well
Morphological changes in the treated and untreated Buffalo grass during the hydrothermal pretreatments were observed using scanning electron microscope. SEM analyses was 

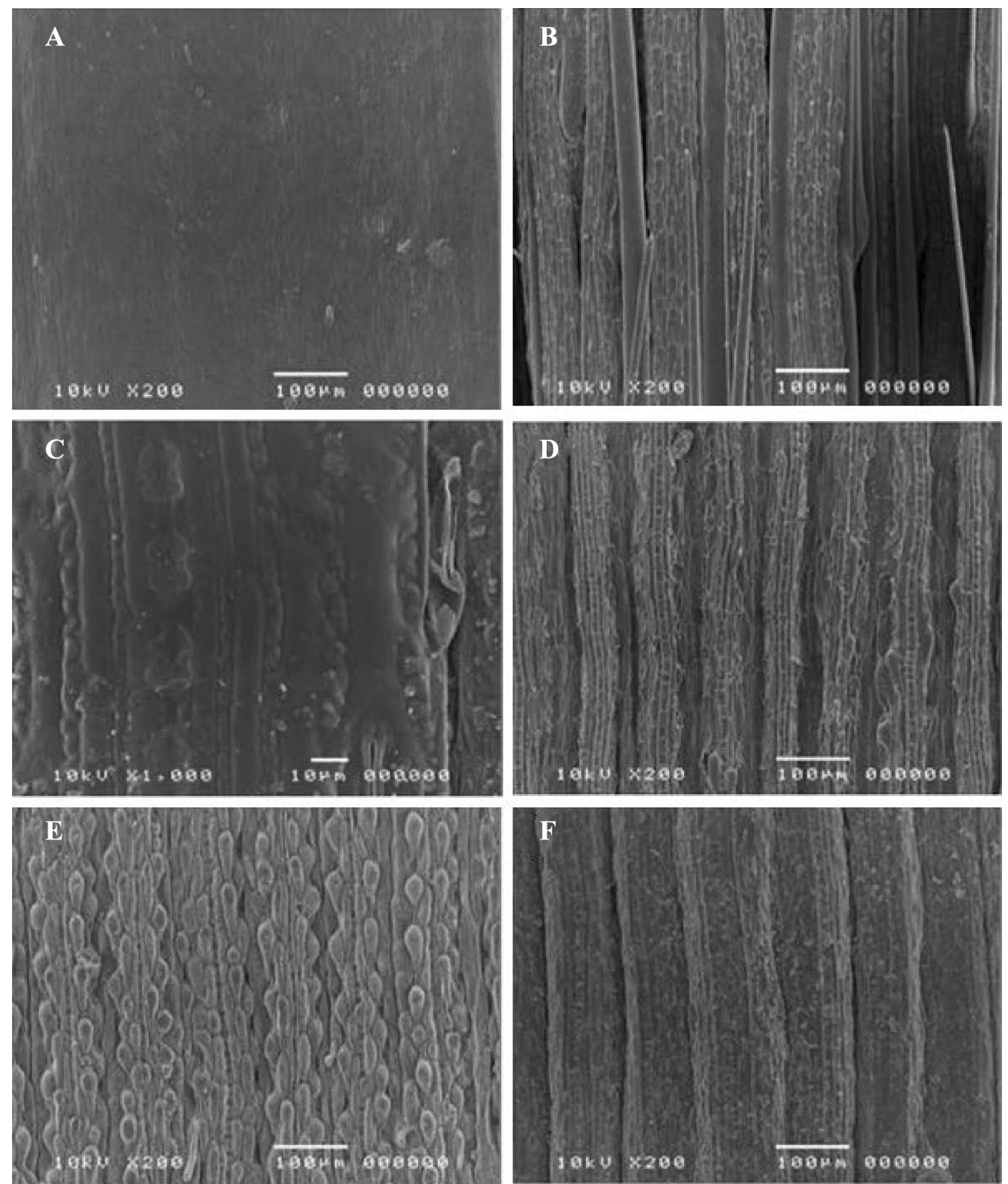

Fig. 4 Scanning electron micrographs of morphological characteristics of non-pretreated and pretreated of buffalo grass samples: a stem (not pretreated), b stem pretreated by boiling, $\mathbf{c}$ upper leaf epidermis

(not pretreated), d pretreated upper leaf epidermis, e lower leaf epidermis (not pretreated) and $\mathbf{f}$ pretreated lower leaf epidermis

(Li et al. 2017). Therefore, hydrothermal pretreatment has been widely applied for facilitating biofuels production (Cybulska et al. 2014). They have long been used for enhancing particulate organic matter disintegration at temperatures from 50 to $270{ }^{\circ} \mathrm{C}$. This study was applied with boiling pretreatment. Batch anaerobic fermentation was conducted to study the biogas potential of boiling preferment with mono

and digestion of buffalo grass with buffalo dung. These experimental results are presented in Table 1 . With $100{ }^{\circ} \mathrm{C}$ boiling water, the buffalo grass produces higher biogas yield and methane content by retention time (i.e., T-III-A $<$ T-III$\mathrm{B}<$ T-III-C $<$ T-III-D $=58.13 \% \mathrm{CH}_{4}<62.17 \% \mathrm{CH}_{4}<63.78$ $\mathrm{CH}_{4} \%<66.10 \mathrm{CH}_{4} \%$. Furthermore, accumulated biogas yield was increased along with retention time. As a study

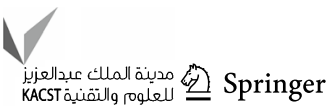


Table 1 The effect of pretreatment and biogas yield

\begin{tabular}{|c|c|c|c|c|c|c|}
\hline \multirow[t]{2}{*}{ Items } & & \multicolumn{5}{|c|}{ Parameters } \\
\hline & & $\mathrm{CH}_{4}(\%)$ & $\mathrm{CO}_{2}(\%)$ & $\mathrm{O}_{2}(\%)$ & $\mathrm{H}_{2} \mathrm{~S}(\mathrm{ppm})$ & $\begin{array}{l}\text { Accumulated } \\
\text { biogas yield } \\
(\mathrm{ml})\end{array}$ \\
\hline No treatment, dung & T-I & 52.27 & 42.8 & 0.1 & $454(0.0454 \%)$ & 8982 \\
\hline No treatment, grass & T-II & 50.34 & 44.5 & 0.1 & $403(0.0403 \%)$ & 7184 \\
\hline Boiled $100^{\circ} \mathrm{C} 0.5 \mathrm{~h}$ (grass) & T-III-A & 58.13 & 39 & 0.1 & $384(0.0384 \%)$ & 9522 \\
\hline Boiled $100^{\circ} \mathrm{C} 1 \mathrm{~h}$ (grass) & T-III-B & 62.17 & 37 & 0.1 & $331(0.0331 \%)$ & 10,975 \\
\hline Boiled $100^{\circ} \mathrm{C} 1.5 \mathrm{~h}$ (grass) & T-III-C & 63.78 & 35.4 & 0.1 & $234(0.0234 \%)$ & 11,047 \\
\hline Boiled $100^{\circ} \mathrm{C} 2 \mathrm{~h}$ (grass) & T-III-D & 66.10 & 33 & 0 & $217(0.0217 \%)$ & 13,185 \\
\hline $\begin{array}{l}\text { Co-digestion of grass } \\
\text { (boiled } 100^{\circ} \mathrm{C} 2 \mathrm{~h} \text { ) and } \\
\text { dung }\end{array}$ & T-IV & 71.00 & 28 & 0 & $132(0.0132 \%)$ & 15,521 \\
\hline
\end{tabular}

result, the main functions of hydrothermal pretreatment on converting the insoluble components into soluble fractions, breaking physical structure, and homogenizing feedstock sizes may improve anaerobic digestion.

The methane production rate reflects the biodegradability and amount of degradable matter. The daily biogas and gas composition including methane, carbon dioxide, hydrogen sulfide and oxygen production characteristics is shown in Figs. 5 and 6. Codigestion is defined as the digestion of mixtures of at least two waste materials for improving AD efficiency. Many successful codigestions of substrates have increased methane potential substantially compared to the mono digestion of the substrates (González-Fernández et al. 2011; Teghammar et al. 2013). These study results clearly demonstrated and agreed with González-Fernández et al. (2011) and Teghammar et al. (2013). Co-digestion of buffalo grass and buffalo dung produced higher accumulated biogas $(15,521 \mathrm{ml})$ and rich methane content $(71 \%)$ compared to mono digestion.

The total solids, volatile solids, chemical oxidation demand, alkalinity, volatile fatty acid and $\mathrm{pH}$ performance on before and after fermentation process was presented in Table 2 and Fig. 7. VFA formed during the acid phase of the anaerobic digestion tends to reduce the system $\mathrm{pH}$, making the methanogenic bacteria, which are sensitive to low $\mathrm{pH}$ values, reduce their activity (Zhang et al. 2008). Thus, a balance between the production and consumption of acid during the refuse biodigestion is essential for the stability of the anaerobic process. The $\mathrm{pH}$ is one of the key factors in $\mathrm{AD}$ and the growth of methanogens can be significantly influenced by the $\mathrm{pH}$ level. VFA can maintain an efficient AD performance by influencing $\mathrm{pH}$ levels and alkalinity. The determination of volatile solids is a good parameter to follow the biodegradable organic matter degradation and its analysis is commonly applied to the biological stability measurement in sludge from liquid effluents (Metcalf and Eddy 1991). The anaerobic stabilization process starts when the volatile suspended solids of the system are hydrolyzed, resulting in soluble COD. The soluble COD represents the soluble organic matter of the system, which in turn is substrate for the methanogenesis, being converted into $\mathrm{CH}_{4}$ and $\mathrm{CO}_{2}$ (Zhang et al. 2008). Carbon is among the main nutrients for the microorganisms, as it is a source of energy for the microbial population; nitrogen is crucial for the microbial population growth (Igoni et al. 2008). Despite the volatile solid values

Fig. 5 Daily biogas production

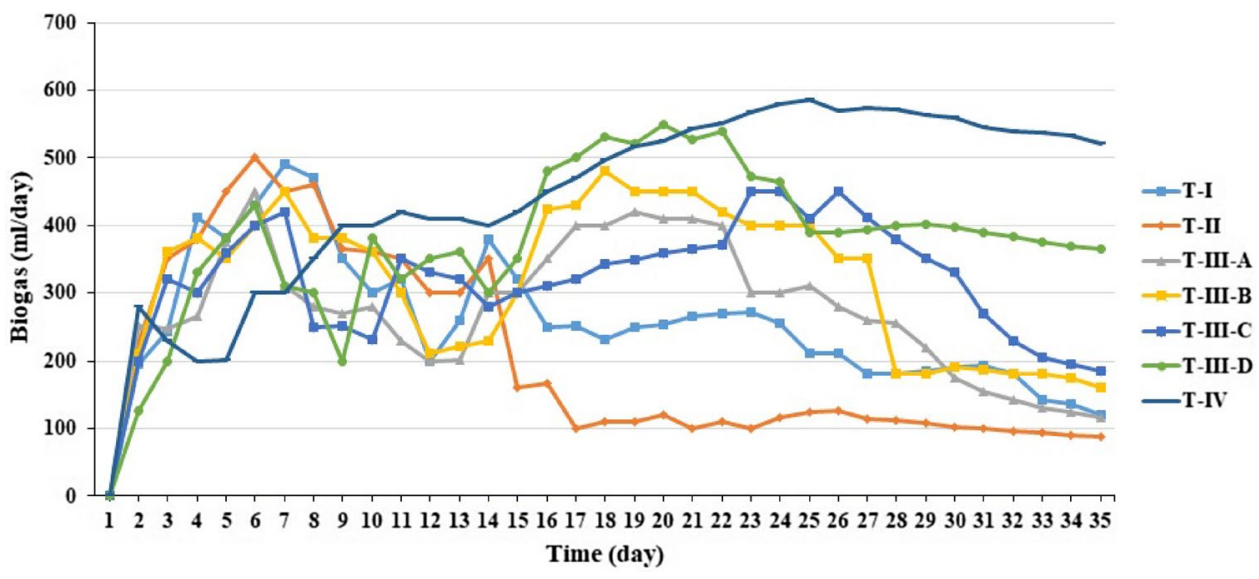



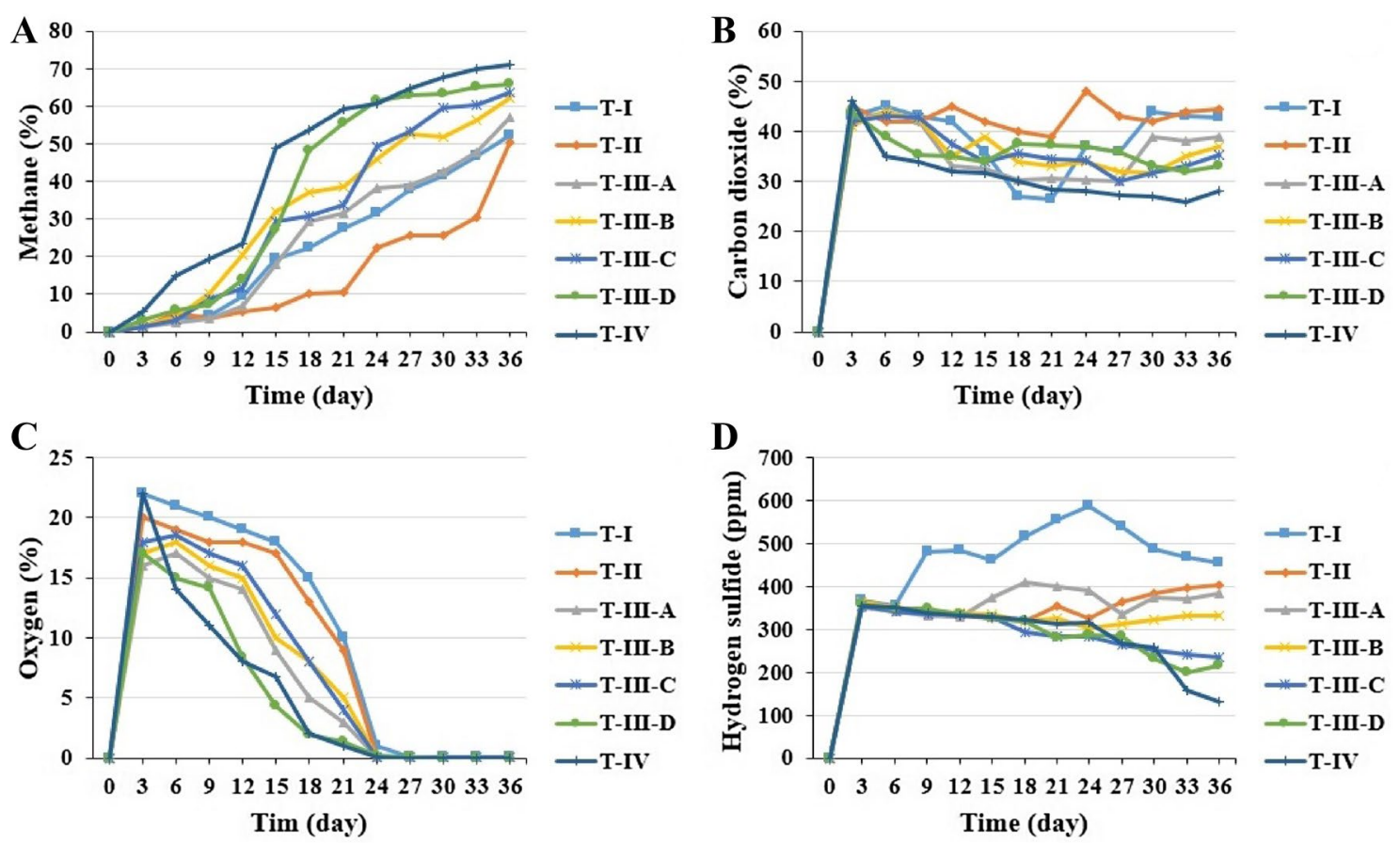

Fig. 6 Biogas composition: a methane, $\mathbf{b}$ carbon dioxide, $\mathbf{c}$ oxygen and $\mathbf{d}$ hydrogen sulfide

Table 2 Alkalinity, volatile fatty acid and $\mathrm{pH}$ performance on before and after fermentation

\begin{tabular}{|c|c|c|c|c|c|c|}
\hline \multirow[t]{2}{*}{ Treatments } & \multicolumn{2}{|c|}{ Alkalinity $\left(\mathrm{mg} / \mathrm{l}-\mathrm{CaCO}_{3}\right)$} & \multicolumn{2}{|c|}{ Volatile fatty acid (mg/l) } & \multicolumn{2}{|l|}{$\mathrm{pH}$} \\
\hline & $\begin{array}{l}\text { Before fer- } \\
\text { mentation }\end{array}$ & $\begin{array}{l}\text { After fer- } \\
\text { mentation }\end{array}$ & $\begin{array}{l}\text { Before fer- } \\
\text { mentation }\end{array}$ & After fermentation & $\begin{array}{l}\text { Before fer- } \\
\text { mentation }\end{array}$ & $\begin{array}{l}\text { After } \\
\text { fermenta- } \\
\text { tion }\end{array}$ \\
\hline T-I & 2400 & 3833 & 3960 & 3844 & 7.55 & 7.06 \\
\hline T-II & 2733 & 3133 & 4013 & 3820 & 7.55 & 6.53 \\
\hline T-III-A & 2533 & 3800 & 4166 & 3912 & 7.55 & 6.55 \\
\hline T-III-B & 2767 & 3233 & 4058 & 3949 & 7.55 & 6.54 \\
\hline T-III-C & 2935 & 3324 & 4195 & 42,477 & 7.55 & 6.51 \\
\hline T-III-D & 2787 & 3143 & 4004 & 3990 & 7.55 & 6.54 \\
\hline T-IV & 2948 & 3072 & 4123 & 4246 & 7.55 & 6.52 \\
\hline
\end{tabular}

being still relatively high at the end of the process, the final carbon values reveal that the biogas production develops to the end in the biodigesters; the TS, VS, and COD degradation efficiency were $79.48,79.72$ and $79.80 \%$, respectively, which were consumed within the 35 days of the biodigestion.

\section{Biogas enhancement through biological process}

There are a number of purification methods that have been applied in some countries, namely absorption of liquids into the physics/chemical; adsorption on the surface of a solid adsorbent, membranes separation, cryogenic separation, and chemical change. However, these technologies showed that there is a high cost to purify biomethane, which is three times higher than that of the biogas production cost. An alternative technique to upgrade biogas is to use photosynthetic $\mathrm{CO}_{2}$ uptake by microalgae. Microalgae have high carbon fixation ability and rapid growth rate, and can be adapted to various environmental conditions (Ramaraj et al. 2016a, b ,c). When microalgae are utilized for biogas upgrading, the photosynthesis can efficiently convert $\mathrm{CO}_{2}$ in raw biogas into its biomass (Tang et al. 2011). This allows the valorization of biogas $\mathrm{CO}_{2}$ in the form of a valuable microalgae biomass, which can be used as feedstock to produce biofuels or even high value-added by-product. In this study, biogas purification and methane enhancement through biological process are presented in Table 3 . 
Fig. 7 Total solids, volatile solids and chemical oxidation demand of before and after fermentation
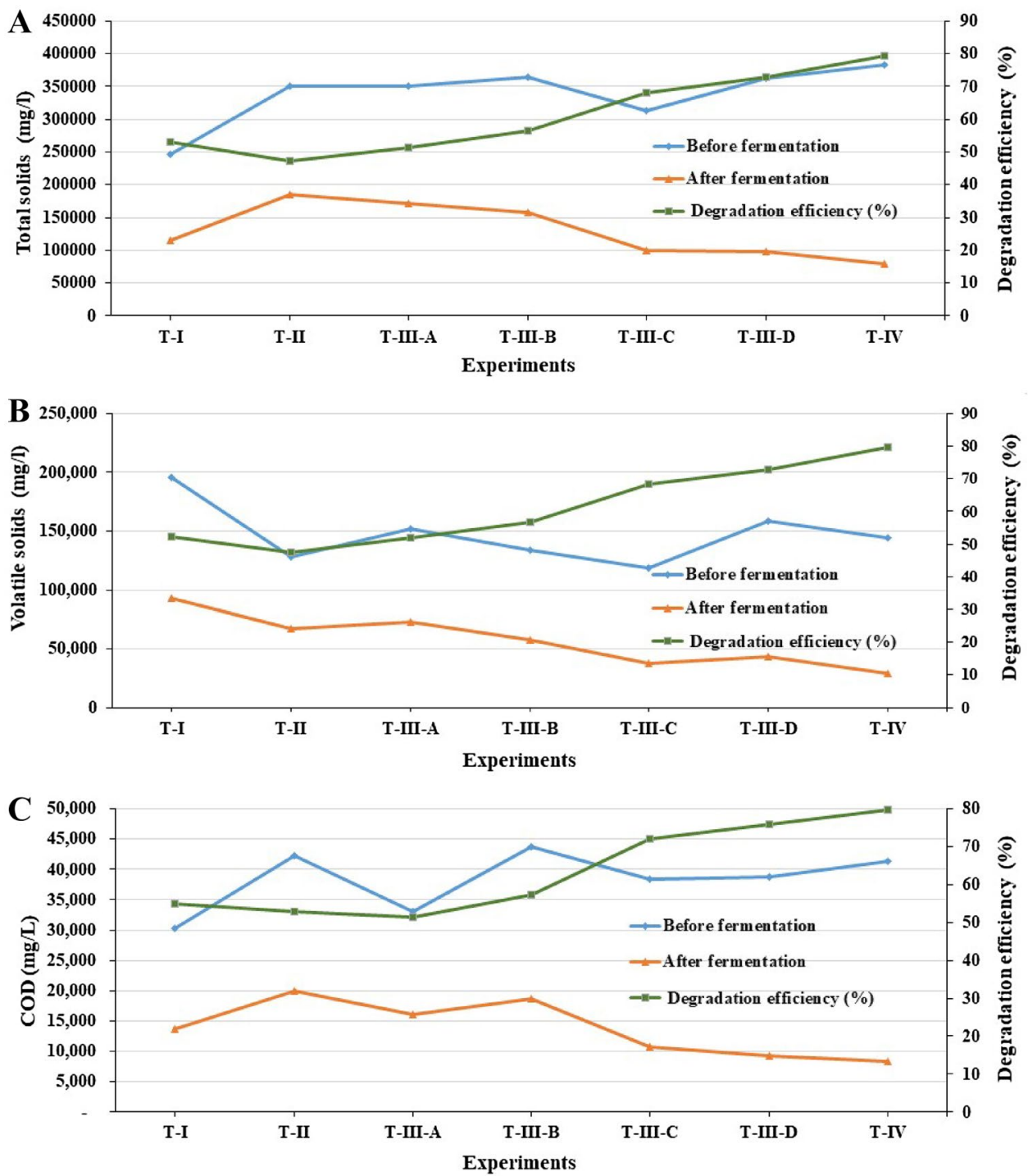

Table 3 biogas purification and methane enhancement through biological process

\begin{tabular}{|c|c|c|c|c|c|c|c|}
\hline \multirow{2}{*}{$\begin{array}{l}\text { Parameters } \\
\text { Biogas composition }\end{array}$} & \multirow{2}{*}{$\begin{array}{l}\text { Performance } \\
\text { Biogas flow rate }\end{array}$} & \multicolumn{6}{|c|}{ Biogas composition (\%) } \\
\hline & & $\mathrm{CH}_{4}(\%)$ & $\mathrm{CO}_{2}(\%)$ & $\mathrm{O}_{2}(\%)$ & $\mathrm{H}_{2} \mathrm{~S}(\%)$ & $\begin{array}{l}\text { Other trace } \\
\text { gases }(\%)\end{array}$ & References \\
\hline Before purification & - & 68.8 & 29.7 & 0 & 0.077 & - & Dussadee et al. (2014) \\
\hline After purification & - & 89.35 & 10.05 & 0.02 & 0.001 & - & \\
\hline Before purification & - & 64.67 & 31.5 & 0 & 0.058 & - & Ramaraj et al. (2016a, b ,c) \\
\hline After purification & - & 82.05 & 17.08 & 1.11 & 0.001 & - & \\
\hline Before purification & - & 71 & 28 & 0 & 0.013 & 0.99 & This study \\
\hline \multirow[t]{2}{*}{ After purification } & $0.9 \mathrm{lpm}$ & 91 & 8.56 & 1.49 & 0 & 0.11 & \\
\hline & $1.8 \mathrm{lpm}$ & 83 & 15 & 1.31 & 0 & 0.65 & \\
\hline
\end{tabular}

Gupta et al. 2014 revealed that $\mathrm{H}_{2} \mathrm{~S}$ might lead to the inhibitory effect on photosynthesis in the bioreactor system. In this is case, the study biogas does not have $\mathrm{H}_{2} \mathrm{~S}$. Therefore, the inhibitory impact of $\mathrm{H}_{2} \mathrm{~S}$ on photosynthesis process that is relevant to biological purification using microalgae was ignored. Basically, $\mathrm{SO}_{3}{ }^{2-}$ is known to inhibit photosynthetic $\mathrm{CO}_{2}$ fixation in plants due to $\mathrm{SO}_{3}{ }^{2-}$ outcompeting $\mathrm{CO}_{2}$ in rubisco and inhibit mitochondrial ATP production 
and this study system does not meet this situation due to the lack of $\mathrm{H}_{2} \mathrm{~S}$. Also, $\mathrm{H}_{2} \mathrm{~S}$ concentrations present in raw biogas up to 3000 ppmv did not exert notable inhibitory effects on microalgae growth (Yan et al. 2016).

Since the metabolism and photosynthesis of microalgae depend on microalgae growth, the law of nutrient and $\mathrm{CO}_{2}$ removal efficiency changed as well as the variation tendency of microalgal growth. Furthermore, this study results revealed that flow rate as a vital factor for biogas purification. Different flowrates (0.9-1.81pm) were achieved methane content of $83 \%-91 \%$, and other biogas components were demonstrated in Table 3. In addition, biogas flow rate $(1.8 \mathrm{lpm})$ exposed the better performance compared to the previous studies (Dussadee et al. 2014; Ramaraj et al. 2016a, b ,c). Zhu (2015) was confirmed that $\mathrm{CO}_{2}$ in biogas can be used as an important carbon source for microalgae cells growth. Also it is not difficult to conclude that $\mathrm{N}$ and $\mathrm{P}$ are more insufficient than carbon sources during the growth of microalgae according to the nutrient removal efficiency results. For the same reason, the $\mathrm{CO}_{2}$ in the biogas was consumed during the photosynthesis of microalgae, so the biogas purification capacity was also improved.

\section{Enhanced biogas calorific value and digestate fertilizer}

Enhanced biogas (from co-digestion of buffalo grass and buffalo dung) $\mathrm{HCV}$ was $36.30 \mathrm{MJ} / \mathrm{m}^{3}$ and $\mathrm{LCV}$ was $32.70 \mathrm{MJ} / \mathrm{m}^{3}$. It was much higher than biogas production from traditional AD (LCV of $18.0-23.4 \mathrm{MJ} / \mathrm{m}^{3}$ and $\mathrm{HCV}$ of $20.0-25.9 \mathrm{MJ} / \mathrm{m}^{3}$ ) (Li et al. 2014); accordingly, these study results verified that high-calorific biogas was obtained in this study system after methane was enriched through biological biogas purification. Finally, the digestate from codigestion of buffalo grass and buffalo dung was analyzed. The study digestate and the literature data are presented in Table 4. Digestate can be defined as liquid from anaerobic decomposition of animal and plant waste. It contains considerable amounts of mineral elements including nitrogen, phosphorus, potassium and others. In terms of rapidity of action, it resembles mineral fertilizers since $\mathrm{N}, \mathrm{P}$ and $\mathrm{K}$ elements are easily available for plants. Govasmark et al. (2011) and Heviánková et al. (2013) proved the possibility of occurrence of pathogenic bacteria and heavy metals in digestate. This is why it is important that digestate is safe for use as a fertilizer and also highlighted the use of digestate as a fertilizer in place of mineral fertilizers (Vázquez-Rowe et al. 2015). Na concentration is an important factor to assess the suitability of effluent irrigation. Phosphorus is essential for microorganism growth. Based on the results obtained in this research, an alternative to mitigate those problems is using

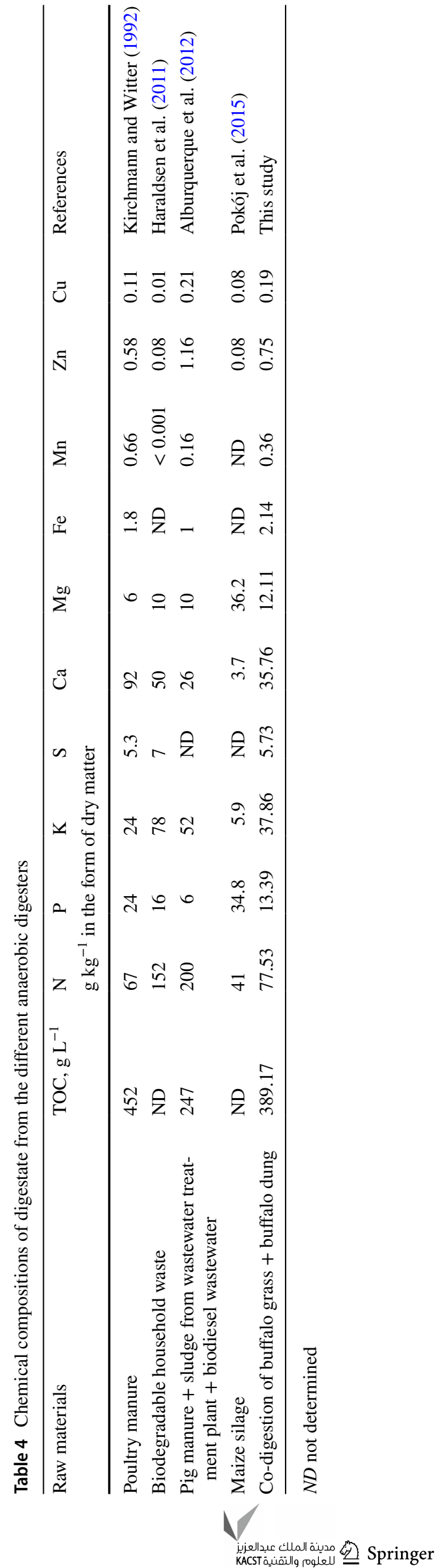


biogas digestate, which could supply the chemical fertilizer demands.

\section{Conclusions}

In the present study, buffalo grass has been established as an efficient cosubstrate for buffalo dung to enhanced biogas production. While buffalo grass is a menacing aquatic biomass, it could also serve as an effective aquatic energy crop with controlled growth and proper maintenance in constructed wetlands and thus reduce the dependency of terrestrial energy crops for bioenergy generation in the near future. More specifically, the methane concentration from the co-digestion mixture was found to be the key parameters for an improved biomethanation process. The microalga biological purification of biogas enrichment was achieved successfully. Furthermore, the digestate from biogas fermenter was confirmed to be an efficient alternative fertilizer with high nutrients and environmentally-friendly comparing to chemical fertilizer.

Acknowledgements The authors thank the following organizations for providing facilities including Energy Research Center (ERC), School of Renewable Energy, Program in Biotechnology (Faculty of Science) and Swine farm (Animal Science and technology), Maejo University, Chiang Mai, Thailand.

\section{Compliance with ethical standards}

Conflict of interest On behalf of all authors, the corresponding author states that there is no conflict of interest.

Open Access This article is distributed under the terms of the Creative Commons Attribution 4.0 International License (http://creativeco mmons.org/licenses/by/4.0/), which permits unrestricted use, distribution, and reproduction in any medium, provided you give appropriate credit to the original author(s) and the source, provide a link to the Creative Commons license, and indicate if changes were made.

\section{References}

Alburquerque J, de la Fuente C, Campoy M, Carrasco L, Najera I, Baixauli C, Caravaca F, Roldán A, Cegarra J, Bernal MP (2012) Agricultural use of digestate for horticultural crop production and improvement of soil properties. Eur J Agron 43:119-128. https:// doi.org/10.1016/j.eja.2012.06.001

APHA (2005) Standard methods for the examination of water and wastewater, American Public Health Association, American Water Works Association, Water Environmental Federation, 21 edn, Washington

Cybulska I, ChaturvediT Brudecki GP, Kadar Z, Meyer AS, Baldwin RM, Thomsen MH (2014) Chemical characterization and hydrothermal pretreatment of Salicornia bigelovii straw for enhanced enzymatic hydrolysis and bioethanol potential. Bioresour Technol 153:165-172. https://doi.org/10.1016/j.biortech.2013.11.071
Deb GK, Nahar TN, Duran PG, Presicce GA (2016) Safe and sustainable traditional production: the water buffalo in Asia. Front Environ Sci 4:38. https://doi.org/10.1016/j.biortech.2013.11.071

Dussadee N, Reansuwan R, Ramaraj R (2014) Potential development of compressed bio-methane gas production from pig farms and elephant grass silage for transportation in Thailand. Bioresour Technol 155:438-441. https://doi.org/10.1016/j.biortech.2013.12.126

Dussadee N, Ramaraj R, Cheunbarn T (2017) Biotechnological application of sustainable biogas production through dry anaerobic digestion of Napier grass. 3 Biotech 7:47. https://doi.org/10.1007/ s13205-017-0646-4

Ennouri H, Miladi B, Diaz SZ, Güelfo LAF, Solera R, Hamdi M, Bouallagui $H$ (2016) Effect of thermal pretreatment on the biogas production and microbial communities balance during anaerobic digestion of urban and industrial waste activated sludge. Bioresour Technol 214:184-191. https://doi. org/10.1016/j.biortech.2016.04.076

González-Fernández C, Molinuevo-Salces B, García-González MC (2011) Evaluation of anaerobic codigestion of micro algal biomass and swine manure via response surface methodology. Appl Energy 88:3448-3453. https://doi.org/10.1016/j.apene rgy.2010.12.035

Govasmark E, Stäb J, Holen B, Hoornstra D, Nesbakk T (2011) Chemical and microbiological hazards associated with recycling of anaerobic digested residue intended for agricultural use. Waste Manage 31:2577-2583. https://doi.org/10.1016/j. wasman.2011.07.025

Guo M, Song W, Buhain J (2015) Bioenergy and biofuels: history, status, and perspective. Renew Sust Energy Rev 42:712-725. https://doi.org/10.1016/j.rser.2014.10.013

Gupta E, Dooley FD, Ward PD (2014) Evolutionary legacy response observed in algae and bryophytes following hydrogen sulfide administration. Toxicol Environ Chem 96:442-450. https://doi. org/10.1080/02772248.2014.944353

Haraldsen T, Andersen U, Krogstad T, Sørheim R (2011) Liquid digestate from anaerobic treatment of source-separated household waste as fertilizer to barley. Waste Manag Res 29:12711276. https://doi.org/10.1177/0734242X11411975

Heviánková S, Kyncl M, Langarová S (2013) Investigating the current management of digestate in the Czech Republic. J Polish Miner Eng Soc 14:119-124

Igoni AH, Ayotamuno MJ, Eze CL, Ogaji SOT, Probert SD (2008) Designs of anaerobic digesters for producing biogas from municipal solid-waste. Appl Energy 85:430-438. https://doi. org/10.1016/j.apenergy.2007.07.013

Kinyua M, Zhang J, Camacho-Céspedes F, Tejada-Martinez A, Ergas S (2016) Use of physical and biological process models to understand the performance of tubular anaerobic digesters. Biochem Eng J 107:35-44. https://doi.org/10.1016/j. bej.2015.11.017

Kirchmann H, Witter E (1992) Composition of fresh, aerobic and anaerobic farm animal dungs. Bioresour Technol 40:137-142. https://doi.org/10.1016/0960-8524(92)90199-8

Li Y, Zhang R, He Y, Zhang C, Liu X, Chen C, Liu G (2014) Anaerobic co-digestion of chicken manure and corn stover in batch and continuously stirred tank reactor (CSTR). Bioresour Technol 156:342-347. https://doi.org/10.1016/j.biortech.2014.01.054

Li Y, Liu H, Yan F, Su D, Wang Y, Zhou H (2017) High-calorific biogas production from anaerobic digestion of food waste using a two-phase pressurized biofilm (TPPB) system. Bioresour Technol 224:56-62. https://doi.org/10.1016/j.biortech.2016.10.070

Metcalf E, Eddy P (1991) Wastewater engineering: treatment, disposal, and reuse, 3rd edn. McGraw-Hill, Inc. International Edition, Singapore

Page AL, Miller RH, Keeney DR (1982) Methods of soil analysis, part 2. chemical and microbiological properties. American Society of 
Agronomy, Crop Science Society of America, Soil Science Society of America Inc, Madison, WI

Pokój T, Bułkowska K, Gusiatin ZM, Klimiuk E, Jankowski KJ (2015) Semicontinuous anaerobic digestion of different silage crops: VFAs formation, methane yield from fiber and non-fiber components and digestate composition. Bioresour Technol 190:201-210. https://doi.org/10.1016/j.biortech.2015.04.060

Ramaraj R, Unpaprom Y, Dussadee N (2016a) Cultivation of green microalga, Chlorella vulgaris for biogas purification. IJNTR 3:117-122

Ramaraj R, Kawaree R, Unpaprom Y (2016b) Direct transesterification of microalga Botryococcus braunii biomass for biodiesel production. Emer Life Sci Res 2:1-7

Ramaraj R, Unpaprom Y, Dussadee N (2016c) Potential evaluation of biogas production and upgrading through algae. IJNTR 2:128-133

Rösch C, Aust C, Jörissen J (2013) Envisioning the sustainability of the production of short rotation coppice on grassland. Energy Sustain Soc 3:1-17. https://doi.org/10.1186/2192-0567-3-7

Saha BC, Yoshida T, Cotta MA, Sonomoto K (2013) Hydrothermal pretreatment and enzymatic saccharification of corn stover for efficient ethanol production. Ind Crops Prod 44:367-372. https:// doi.org/10.1016/j.indcrop.2012.11.025

Sahoo D, Ummalyma SB, Okram AK, Sukumaran RK, George E, Pandey A (2017) Potential of Brachiaria mutica (Para grass) for bioethanol production from Loktak Lake. Bioresour Technol 242:133-138

Strevett KA, Vieth RF, Grasso D (1995) Chemo-autotrophic biogas purification for methane enrichment: mechanism and kinetics. Chem Eng J Biochem Eng J 58:71-79. https://doi. org/10.1016/0923-0467(95)06095-2

Tang D, Han W, Li P, Miao X, Zhong J (2011) $\mathrm{CO}_{2}$ biofixation and fatty acid composition of Scenedesmus obliquus and Chlorella pyrenoidosa in response to different $\mathrm{CO}_{2}$ levels. Bioresour Technol 102:3071-3076. https://doi.org/10.1016/j.biortech.2010.10.047

Teghammar A, Castillo MP, Ascue J, Niklasson C, Horváth IS (2013) Improved anaerobic digestion by the addition of paper tube residuals: pretreatment, stabilizing, and synergetic effects. Energy Fuels 27:277-284. https://doi.org/10.1021/ef301633x

Tsai DDW, Ramaraj R, Chen PH (2016) Carbon dioxide bio-fixation by algae of high rate pond on natural water medium. Ecol Eng 92:106-110. https://doi.org/10.1016/j.ecoleng.2016.03.021
Unpaprom Y, Ramaraj R, Whangchai K (2017) A newly isolated green alga, Scenedesmus acuminatus, from Thailand with efficient hydrogen production. Chiang Mai J Sci 44:1270-1278

Van Soest PJ, Robertson JB, Lewis BA (1991) Methods for dietary fiber, neutral detergent fiber, and nonstarch polysaccharides in relation to animal nutrition. J Dairy Sci 74:3583-3597. https:// doi.org/10.3168/jds.S0022-0302(91)78551-2

Vázquez-Rowe I, Golkowska K, Lebuf V, Vaneeckhaute C, Michels E, Meers E, Benetto E, Koster, D (2015) Environmental assessment of digestate treatment technologies using LCA methodology. Waste Manage 43:442-459. https://doi.org/10.1016/j.wasma n.2015.05.007

Vu PT, Unpaprom Y (2017) Ramaraj R (2017) Evaluation of bioethanol production from rice field weed biomass. Emer Life Sci Res 3:42-49. https://doi.org/10.7324/ELSR.2017.324249

Vu PT, Unpaprom Y, Ramaraj R (2018) Impact and significance of alkaline-oxidant pretreatment on the enzymatic digestibility of Sphenoclea zeylanica for bioethanol production. Bioresour Technol 247:125-130. https://doi.org/10.1016/j.biortech.2017.09.012

Wannapokin A, Ramaraj R, Unpaprom Y (2017) An investigation of biogas production potential from fallen teak leaves (Tectona grandis). Emer Life Sci Res 3:1-10. https://doi.org/10.7324/ ELSR.2017.31110

Wannapokin A, Ramaraj R, Whangchai K, Unpaprom Y (2018) Potential improvement of biogas production from fallen teak leaves with co-digestion of microalgae. https://doi.org/10.1007/s1320 5-018-1084-7

Yan C, Zhu L, Wang Y (2016) Photosynthetic $\mathrm{CO}_{2}$ uptake by microalgae for biogas upgrading and simultaneously biogas slurry decontamination by using of microalgae photobioreactor under various light wavelengths, light intensities, and photoperiods. Appl Energy 178:9-18. https://doi.org/10.1016/j.apenergy.2016.06.012

Zhang P, Zeng G, Zhang G, Li Y, Zhang B, Fan M (2008) Anaerobic co-digestion of biosolids and organic fraction of municipal solid waste by sequencing batch process. Fuel Process Technol 89:485-489. https://doi.org/10.1016/j.fuproc.2007.11.013

Zhu L (2015) Microalgal culture strategies for biofuel production: a review. Biofuels Bioprod Biorefin. https://doi.org/10.1002/ bbb. 1576 